Beyond Philology No. 15/1, 2018

ISSN 1732-1220, eISSN 2451-1498

\title{
Developing intercultural competence in an academic foreign language classroom
}

\author{
MONIKA KUSIAK-PISOWACKA
}

Received 15.10.2017,

received in revised form 2.06 .2018 ,

accepted 29.06.2018.

\begin{abstract}
This paper focuses on the issue of developing intercultural communicative competence (ICC) in a higher education context, with a special focus put on teaching advanced foreign language (FL) students. First, the concept of ICC is discussed on the basis of Byram's (1997) theory, which is still considered the most comprehensive model for describing the principles of developing and assessing intercultural competence in foreign language teaching. Next, a short overview of studies related to teaching ICC conducted by Polish researchers is presented. This is followed by a description of an Intercultural Communication course designed for university students and conducted by the author of the paper. In this report, the theoretical principles, the main aims of the course along with the techniques applied in teaching and evaluating students are discussed. It is hoped that the paper will be a useful contribution to discussions concerning developing ICC and will stimulate further research in this interesting area of education.
\end{abstract}

\section{Keywords}

intercultural communicative competence, teaching in academia, Byram's model, evaluating intercultural competence 


\title{
Kształcenie kompetencji interkulturowej u studentów filologii angielskiej
}

\begin{abstract}
Abstrakt
Artykuł jest kolejnym głosem w dyskusji dotyczącej rozwoju interkulturowej kompetencji komunikacyjnej (IKK), tym razem w kontekście kształcenia studentów filologii angielskiej. Na wstępie wyjaśnione jest pojęcie IKK w odniesieniu do modelu Byrama (1997), którego kompleksowa teoria nadal uważana jest za szczególnie przydatna $\mathrm{w}$ badaniach dotyczacych kształtowania i oceniania tej kompetencji. Następnie przedstawiony jest krótki przegląd badań przeprowadzonych w Polsce dotyczacych nauczania IKK. Główna część artykułu stanowi opis kursu, który został przeprowadzony przez autorkę artykułu w szkole wyższej. Omówione sa zasady teoretyczne, główne cele kursu oraz techniki stosowane w czasie nauczania i oceniania studentów. Autorka ma nadzieję, że artykuł zachęci nauczycieli i badaczy do dalszych badań w tej interesującej dziedzinie edukacji.
\end{abstract}

\section{Słowa kluczowe}

interkulturowa kompetencja komunikacyjna, nauczanie w szkole wyższej, model Byrama, ocenianie kompetencji interkulturowej

\section{Introduction - the importance of developing ICC in academia}

Developing intercultural communicative competence (ICC) has become an important goal of foreign language (FL) education. The role of school instruction is not only to equip FL learners with appropriate language skills, but also to prepare students to understand FL cultures and successfully communicate with their representatives. As they regard higher education, the clear aims concerning this aspect of education are explained in National Qualifications Framework for Higher Education (in Polish Krajowe Ramy Kwalifikacyjne) which, since 2012, has 
served as a qualifications framework for all study programmes in higher education institutions in Poland.

According to the above-mentioned document, during their studies students should acquire specialized knowledge and develop a wide range of abilities, one of which is being able to communicate in an international environment. Although the present paper is concerned with enhancing ICC in English philology students, it goes without saying that students of other faculties should also be trained in this skill.

Intercultural communicative competence has become a focus of a number of studies conducted within the discipline of academic teaching, examined both in more theoretically oriented studies and in those aiming to approach this subject area in a more practical manner. This paper will discuss only the studies that focus on practical aspects related to teaching.

With regard to the theoretical principles of developing ICC, most of the studies presented below refer to Byram's (1997) model of intercultural communicative competence, the theory recommended in The Common European Framework (The Council of Europe) as a basis for defining the competencies of FL learners. In brief, the aforementioned model defines ICC as a combination of five elements that should be developed in FL teaching: attitudes, acquiring knowledge, skills of interpreting and relating, skills of discovery and interaction, and critical cultural awareness. Developing attitudes embraces showing learners how to be open and willing to communicate. Acquiring knowledge refers to learning about one's own and other cultures, their products and policies, daily life, history, art, institutions and non-verbal behavior. Developing skills of interpreting and relating involves equipping students with the ability to interpret a document or event from another culture as well as showing students how to explain and relate to documents or events from one's own culture. Training skills of discovery and interaction means developing an understanding of a new environment and an ability to interact with its representatives. A crucial aim of the intercultural approach suggested by 
Byram (1997), in my opinion especially important in teaching adult learners, is enhancing critical cultural awareness. It entails practicing critical thinking in relation to one's own culture and the foreign one, which results in viewing other cultures in a more objective way and being aware of potential areas of conflict. The guidelines highlighted in the model have served as a point of reference for educators in their efforts to design curricula based on the intercultural approach. The model has also been a source of inspiration in the process of designing classroom activities.

\section{The intercultural approach in the Polish educational context}

A substantial number of studies focus on practical issues related to incorporating the intercultural component in FL teaching, such as materials and techniques applied in teaching, and problems encountered by teachers and learners. A selection of teaching-oriented studies conducted by Polish researchers is presented below.

Siek-Piskozub (2016) stresses the advantages of a microetnographic approach, which involves studying text or watching video materials and discussing their intercultural content. Media is also a crucial component of the approach suggested by Wilczyńska (2013). Following The Recommendation of the European Parliament on key competences for lifelong learning, she suggests an integrated approach in which learners develop media communication skills along with intercultural competence. Wilczyńska (2013: 182) explains that "IC competence implies personal development, openness and critical thinking, all of these contributing to the improvement of cross-cultural communication in our global village." Also PiotrowskaPaprocka (2007) suggests that students watch TV commercials and newspaper advertisements, e.g. based on stereotypes. Exchanging opinions about stereotypical ideas expressed in the given material is likely to raise students' awareness about their 
own knowledge of other cultures and facilitate their understanding of possible sources of intercultural conflicts.

A similar technique that can enable students to challenge their attitudes to foreign cultures is acultural training suggested by Jankowska and Bodzioch (2016). The training is based on simulations that illustrate situations that may lead to intercultural problems. For example, by playing the roles of members of two different cultures: monochronic (demanding punctuality from others) and polychronic (not respecting rules concerning time), students can experience problems that the two cultures may encounter and talk about their understanding of the problematic situation.

As emphasized earlier, a crucial element of building intercultural competence is developing awareness of one's own culture. Aleksandrowicz-Pędich (2009) suggests activities that can encourage learners to gain insights into their own culture, such as examining their daily routines, social practices and non-verbal behavior. Aleksandrowicz-Pędich (2009: 32) believes, referring to Kapuściński (2006: 14), that: "to understand yourself better, you have to learn about the Others, because they are the mirror in which we see ourselves. Through looking at the Other we may better understand our own culture, behavior and emotions, and only then can we try to explain ourselves to the Other."

Strugielska (2016) and Dryjańska (2016) recommend a linguistic perspective as a theoretical foundation for developing ICC. Strugielska (2016) bases her approach on cognitive linguistics and Kramsch's (2010) idea that in analysing culture one needs to look at abstract concepts (such as democracy or pluralism) that function in a given culture. Strugielska's course "Metaphors across Europe: language, culture and the mind", which was prepared for an international group of Erasmus Plus students, is an example of how both cognitive linguistics and intercultural communication theories can be successfully integrated in intercultural training. Drawing on Wierzbicka's (2013) cross-cultural linguistics, Dryjańska 
(2016) advocates a reflective approach to one's native language and a foreign language. For example, students can be asked to reflect on the meaning of value words, i.e. vocabulary items that express certain values, taken from different languages, e.g. friend (Eng.) and przyjaciel (Polish).

An interesting type of research project focusing on ICC is the international project, conducted by educational institutions. An example is a joint project of the Jagiellonian University in Krakow, Poland and the National University in IvanoFrankivsk, Ukraine, entitled: Developing intercultural competence through English. The outcome of the project is a collection of essays edited by Niżegorodcew, Bystrov, Kleban (2011), in which Polish and Ukrainian writers, both scholars and university students, discussed issues about their culture which could be of interest to foreigners. Aleksandrowicz-Pędich (2011) , the reviewer of the book, observed an interesting difference between the authors of the essays: Ukrainians wrote about the attractive aspects of their own culture, such as Ukrainian customs and traditions; whereas Polish authors focused on problematic and difficult issues, e.g. the attitude of Polish people towards religion. It is worth emphasizing that several essays produced by students within this international project became an important part of the Intercultural Communication (IC) course which is the focus of this paper and which is described in the next section of the text.

\section{A description of the IC course conducted in an academic classroom}

\subsection{Course participants}

The "Intercultural Communication" course consisted of 20 classes of 45 minutes each. Although it was not implemented as a part of a practical English class, its subsidiary aim was to enable the students to develop their FL competence. The participants were first year students of English philology; most of 
them planning to join an "English in business" specialization in their second year of studies. Their level of English was upper-intermediate (CEFR B2). There were 40 students taught as 2 groups, each consisting of 20 students. It is important to emphasize that the course was not homogenous -20 students were Ukrainian, 15 students were Polish and 5 students were Spanish Erasmus students.

\subsection{Theoretical principles of the course: Contrasting student and teacher understanding of culture and intercultural communication}

Before embarking on the task of designing the course and preparing teaching materials, I considered it crucial to define the concepts of culture and intercultural communication as well as to decide on how these concepts would be operationalized in the course. I also found it useful to interview my students about their understanding of the two concepts.

At the beginning of the course, the students were asked two questions. First: "How do you understand the terms culture and intercultural communication?" and second: "What would you like to learn during the course?" The students were asked to discuss these questions in small groups, followed by a class discussion. This short exercise revealed that for most of the students culture meant the culture of a foreign country and intercultural communication involved being able to communicate with foreigners. The students considered intercultural communication skills to be useful both in travelling abroad and in their future jobs. It is interesting to note that my students' understanding of culture was similar to the opinions expressed by the students of Piller (2007), who in her publication presents similar experiences from teaching an IC course.

In contrast to the students' views, my definition of culture was not limited to nationality. Following Scollon and Scollon (2000) and their discourse approach , grounded in interactional sociolinguistics and discourse analysis, I assumed that dis- 
tinct cultural groups manifest specific discourses and that intercultural communication can be viewed as interdiscourse communication. For the purpose of the course, I decided to operationalize the concept of culture in a clear way, which helped me in the process of selecting materials and designing activities. When teaching the course, I drew on the assumption that a specific culture is constructed by members of a group or a community through their own ways of thinking, behaviors (routines) and ways of communicating within a group (members of the group) as well as with representatives of other groups/communities (outsiders). As regards Intercultural Communication Competence, following Byram (1997) I viewed it as a combination of three components: knowledge, skills and attitudes. Thus, developing ICC meant both developing knowledge, skills and attitudes that can facilitate understanding of one's culture and the culture of the other, as well as developing the ability to communicate with the members of one's group and with representatives of other groups.

\subsection{Course aims}

In FL education, Intercultural Training bears some similarity to CLIL (content and language learning learning). Both approaches aim at developing learners' FL competence and knowledge of the subject, which in the case of intercultural training is culture. Therefore, the aims of the course would embrace both FL competence and the intercultural content. IC content would refer to the following:

- Knowledge, i.e. learning more about different cultures (e.g. countries, groups of people) and their customs, traditions, ways of thinking;

- Skills, i.e. improving the skills of discussing various aspects of intercultural communication; becoming more aware of possible conflicts between different cultures; reflecting on the culture of one's own country; reflecting on oneself as a mem- 
ber of certain cultures and one's skills to communicate with other cultures;

- Attitudes, i.e. developing tolerance towards members of other cultures (i.e. those to which students do not belong).

In reference to FL competence, the aims would focus on developing reading skills (also reading the Internet materials), writing skills, speaking skills, presentation skills and the ability to cooperate with other students.

\subsection{Content and materials}

A variety of material was used in the course. While there is merit to introducing a linguistic perspective in teaching university students, as Dryjańska (2016) did, ultimately that option was not taken in this course. The primary reason for excluding the linguistic perspective was the fact that the participants of the course were the first year students and their level of FL competence was an unknown factor. Instead, it was determined that a potentially more effective approach would be to introduce elements of personalization. With reference to input, it would mean having students watch materials in which people of their age were the main characters and reading texts concerning issues important to the students, and, if possible, also written by other students. In reference to output, the personalization would entail inviting the students to express their opinions about issues which they considered interesting and worth discussing. A list of the main materials along with the topics and teaching goals are enumerated below in Table 1 . It is important to emphasize that most of these materials facilitated personalization. The chapters from "Developing intercultural competence through English: Focus on Ukrainian and Polish cultures" are essays written by Polish and Ukrainian students, "Educating Rita" is a film about an unusual student, and the POLANDIA videos are interviews with young foreigners, often university students who, during their visit to Poland, present their opinions about Poland and their native countries. 
Although the intention was not to overburden the students with theories underpinning contemporary intercultural research, such as the Hofstede model of dimensions of national cultures, the Hofstede model was implemented in a very practical way by encouraging the class to reflect on certain differences between countries.

\section{Table 1}

The content of the IC classes (topics and materials)

\begin{tabular}{|c|c|c|}
\hline Topics and materials & Activities & Aims \\
\hline $\begin{array}{l}\text { What is culture? What } \\
\text { is intercultural } \\
\text { communication? } \\
\text { What culture do we } \\
\text { belong to? What } \\
\text { culture(s) do we } \\
\text { construct and how do } \\
\text { we do it? }\end{array}$ & $\begin{array}{l}\text { class discussion } \\
\text { guided by the teacher }\end{array}$ & $\begin{array}{l}\text { - to encourage } \\
\text { students to verbalize } \\
\text { their own understand- } \\
\text { ings of the main } \\
\text { concepts of the course, } \\
\text { i.e. culture and } \\
\text { intercultural } \\
\text { communication }\end{array}$ \\
\hline $\begin{array}{l}\text { selected chapters from } \\
\text { Niżegorodcew, Bystrov, } \\
\text { Kleban (eds.), } \\
\text { "Developing } \\
\text { intercultural } \\
\text { competence through } \\
\text { English: Focus on } \\
\text { Ukrainian and Polish } \\
\text { cultures" }\end{array}$ & $\begin{array}{l}\text { reading the texts, } \\
\text { group and class } \\
\text { discussions }\end{array}$ & $\begin{array}{l}\text { - to sensitize students } \\
\text { to the phenomenon of } \\
\text { positive and negative } \\
\text { stereotypes, e.g. } \\
\text { stereotypes about } \\
\text { Ukrainian men and } \\
\text { women } \\
\text { - to encourage } \\
\text { students to reflect on } \\
\text { their role in } \\
\text { a community of } \\
\text { university students by } \\
\text { discussing the } \\
\text { question whether } \\
\text { Polish students cheat } \\
\text { at exams }\end{array}$ \\
\hline $\begin{array}{l}\text { "Educating Rita", } \\
\text { a film available on } \\
\text { YouTube }\end{array}$ & $\begin{array}{l}\text { watching the film, } \\
\text { discussions, writing an } \\
\text { essay (a homework } \\
\text { assignment) }\end{array}$ & $\begin{array}{l}\text { - to enable students to } \\
\text { see factors } \\
\text { contributing to various } \\
\text { kinds of conflicts } \\
\text { (between family } \\
\text { members, friends, } \\
\text { social classes) } \\
\text { - to invite students to } \\
\text { reflect on themselves } \\
\text { as those who } \\
\text { "participate" in conflict } \\
\text { situations }\end{array}$ \\
\hline
\end{tabular}




\begin{tabular}{|c|c|c|}
\hline $\begin{array}{l}\text { "POLANDIA" - } \\
\text { interviews with } \\
\text { foreigners about } \\
\text { Poland; films available } \\
\text { on YouTube }\end{array}$ & $\begin{array}{l}\text { watching the interview } \\
\text { with the Norwegian girl } \\
\text { studying in Poland, } \\
\text { discussions }\end{array}$ & $\begin{array}{l}\text { - to discuss the } \\
\text { opinions expressed by } \\
\text { the Norwegian girl } \\
\text { concerning various } \\
\text { aspects of Polish } \\
\text { culture } \\
\text { - to discuss the } \\
\text { meaning of tolerance } \\
\text { as a feature in } \\
\text { intercultural } \\
\text { communication }\end{array}$ \\
\hline $\begin{array}{l}\text { "18 surprising things } \\
\text { you didn't know about } \\
\text { Poland", a film } \\
\text { available on YouTube }\end{array}$ & $\begin{array}{l}\text { watching the video, } \\
\text { discussions }\end{array}$ & $\begin{array}{l}\text { - to practice the skill to } \\
\text { distinguish facts from } \\
\text { opinions }\end{array}$ \\
\hline $\begin{array}{l}\text { differences between } \\
\text { countries on the basis } \\
\text { of the comparisons } \\
\text { made by Hofstede - } \\
\text { materials available } \\
\text { online }\end{array}$ & $\begin{array}{l}\text { discussing the graphs } \\
\text { concerning differences } \\
\text { between Poland, the } \\
\text { United Kingdom and } \\
\text { Germany in the } \\
\text { following features: } \\
\text { power distance, } \\
\text { individualism, } \\
\text { masculinity, } \\
\text { uncertainty avoidance, } \\
\text { long term orientation } \\
\text { and indulgence }\end{array}$ & $\begin{array}{l}\text { - to encourage } \\
\text { students to express } \\
\text { their opinions about } \\
\text { the differences } \\
\text { between countries } \\
\text { suggested by Hofstede } \\
\text { - to practice the skill to } \\
\text { justify opinions } \\
\text { presented in the } \\
\text { discussion }\end{array}$ \\
\hline $\begin{array}{l}\text { the nature of a culture } \\
\text { shock and the process } \\
\text { of adjustment }\end{array}$ & $\begin{array}{l}\text { class discussion } \\
\text { stimulated by the } \\
\text { teacher }\end{array}$ & $\begin{array}{l}\text { - to encourage } \\
\text { students to talk about } \\
\text { their own experiences } \\
\text { related to a culture } \\
\text { shock }\end{array}$ \\
\hline
\end{tabular}

An important component of the course was the use of homework assignments. The first assignment was to write an essay: "Educating Rita is a film about intercultural conflicts. Discuss." The next assignment was to prepare a powerpoint presentation, in pairs or small groups, about any intercultural issue which the students found interesting and present it to the whole group. 


\section{Course evaluation - the students' voice}

In order to obtain the students' opinions about the classes, a questionnaire was administered at the end of the course (see the Appendix). Unfortunately only 17 students completed it; the others were absent. The students were asked to express their opinions about various elements of the course and evaluate the effectiveness of the classes in relation to their own intercultural competence. Table 2 presents the results obtained related to the particular sections of the questionnaire; the numbers provided stand for the mean scores of the data obtained. The results are ordered from the items that obtained the highest mean scores to those that obtained the lowest ones.

\section{Table 2}

The results of the questionnaire the students completed after the course

To what extent the IC classes helped the students to develop the following aspects of IC competence (questions 1-8):

- understanding why different cultures may experience difficulty in communicating: 4.24

- understanding members of other cultures: 4.24

- learning about different cultures, their customs, traditions, ways of thinking: 4.12

- developing tolerance towards members of other cultures: 4.06

- reflecting on oneself as a member of some cultures and skills to communicate with other cultures: 3.88

- improving the skills of discussing various aspects of intercultural communication: 3.76

- becoming aware of possible conflicts between different cultures: 3.65

- reflecting on the culture of my own country: 3.65

What elements of FL competence the students developed during the IC classes (questions 10-14):

- speaking skills: 4.47

- cooperating with other students: 4.35

- presentation skills: 4.29

- writing skills: 4.12

- reading skills (also reading the Internet materials): 3.53 
Evaluation of the topics discussed during the IC classes (questions 15-21):

- stereotypes about Ukrainian men and women: 4.41

- 18 interesting things about Poland (a fact or a stereotype): 4.29

- the interview with the Norwegian girl studying in Poland: 4.24

- intercultural conflicts in 'Educating Rita': 4.18

- Polish students cheating at exams: 4.06

- differences between different countries: 3.53

- the nature of an intercultural shock: 3.18

Evaluation of the activities of the IC classes (questions 22-29):

- watching a film: 4.88

- watching YouTube videos: 4.53

- the teacher's presentation: 4.41

- discussions about the material read or watched: 4.41

- watching other students' presentations: 4.29

- writing an essay: 3.88

- reading articles: 3.82

- preparing and conducting the presentation: 3.76

With respect to developing IC competence, on the basis of the mean scores, it can be implied that the students observed improvement in all the skills ${ }^{1}$ enumerated in the questionnaire, although to different degrees. For example, "understanding why different cultures may experience difficulty in communicating" and "learning about different cultures" received the highest scores. However, "becoming more aware of possible conflicts between different cultures" and "reflecting on the culture of one's own country" were the skills that the students improved to the lesser extent.

The analysis of the answers concerning how the IC classes helped the students to develop their FL competence (questions 10-14) showed that in the students' opinions, speaking skills and cooperating with other students are the skills that the students developed to a greater degree than writing and reading. Questions 15-21 asked the students to evaluate the topics discussed during the classes. The results showed that "ste-

1 For the sake of simplification, in this analysis only the term "skill" is used without distinguishing between attitudes, knowledge and skills. 
reotypes about Ukrainian men and women" were the most popular, while "discussing differences between countries" and "the nature of an intercultural shock" were the least popular. Regarding the activities of the classes, the mean scores showed that watching YouTube videos, the teacher's presentations and the class discussions were the most valued by the students. Preparing and conducting the presentation, writing and reading activities were evaluated as the least valued.

The students were also asked a few open questions. They commented on the presentations they were required to prepare and gave their suggestions concerning the IC course. The students liked the following aspects of the presentation task: the opportunity to cooperate with other students, working on topics of the students' choice, and searching for information on the internet. The following quotations emphasize some other advantages of this form of learning: "it was fun to see the reaction of some students when they heard some facts about their culture", "it was a new experience for me". There were some things the students did not like about the presentation task, such as stress before the presentation, not having enough time to present everything which had been prepared, technical problems with cooperating with other classmates and problems with finding appropriate materials.

The students suggested the following topics that they would have liked to discuss if they were to take the course again: how one's upbringing can influence the way he/she behaves later, Afro-American culture, hip-hop culture, cultural differences that influence intercultural terrorism, English as lingua franca, how the internet influences communication in the world, taboo topics ("they are still around us") and more information about Poland and Ukraine (since " it can help us to communicate with each other"). For activities in the IC course, the students indicated that they would have appreciated more discussions, and watching interviews with foreigners, but definitely wanted to do less reading. The last question elicited general comments about the course. The most interesting comments 
were: "I was impressed by how multicultural our groups were", "the classes were relaxing", "we did not have to write a test".

\section{Course reflection - the teacher's voice}

An evaluation of the course is presented below. In it, I draw upon my observation of the classes, reflect on my role as a teacher, and consider the students' participation. I also refer to the answers elicited from the students in the questionnaire.

With respect to the aims concerning developing FL competence and IC, it is difficult to evaluate to what extent they were achieved. During the course I observed genuine interest on the part of the students in the topics discussed - the students were eager to do all the tasks, particularly those which involved watching films or YouTube videos and discussions. However, I noticed certain problems the students had when reading the texts and approaching cultural topics from a more theoretical perspective, e.g. discussing differences between countries according to the Hofstede classification. My observations were confirmed by the results obtained from the questionnaire (see Table 2) which show that reading and writing activities were ranked as those that the students liked the least. To conclude, since there was no test measuring students' FL competence before and after the classes, it is impossible to say to what extent the students developed their FL skills. It seems that the activities based on watching films were perceived by the students as easier and thus more attractive, which can mean that they could have been more effective as materials meant to enhance students' ICC.

An important question to answer is to what extent did the IC classes help the students to develop IC competence. I was glad to see that the students' answers obtained in the first section of the questionnaire imply that the learners developed all of the intercultural skills enumerated in the questionnaire, although not to the same extent. The skills that were ranked as those developed to a lesser degree are the skill of being 
aware of possible conflicts between different cultures and the skill of reflecting on the culture of one's own country. It is difficult to explain this result. Although undoubtedly the course created many opportunities for the students to enhance their IC skills, it is hard to say which activities were more effective in this particular respect.

It is worth focusing on the presentations which the students prepared and performed in class. The answers from the questionnaire show that this task was stressful for some students; they preferred watching other students' presentations to preparing and conducting their own presentation. Although it seems that the learners found the presentation task difficult, their performance and the quality of the presented materials was quite good. The students presented on a wide variety of topics, not directly connected with those discussed during the classes, such as: reading habits in different countries, Polish Ukrainian cuisine, education, body language, migration problems, changing attitudes to marriage, intercultural couples, Polish - Spanish stereotypes, celebrating festivals in different countries, the role of music in our life, football fans, and religion. All of the presentations reflected the students' personal understanding of what intercultural issues are and their genuine involvement in the task.

Another advantage of observing the presentations is that they enabled me to see incidents which can be treated as evidence of the students' developing their ICC. One example is the use of the word "normal" by the speaker, e.g. in the phrases "normal religion", "normal church") and the pronoun "we", "our". Although the author of the presentation was confident in using the words, the audience seemed not to understand and demanded clarification of what exactly the speaker meant. This example shows that the students are critical listeners and demonstrates their ability to discuss the issue. It seems that this situation raised the students' awareness that it is difficult to be objective when discussing intercultural issues. The other incident concerns evaluation of the data that 
the author of the presentation found on the internet. A Polish student decided to prepare a presentation about Ukrainian customs on the basis of the materials found on the internet. To his great surprise, most of the information was evaluated by the Ukrainian students as not true. This incident raised the students' awareness of the quality of the internet as a source of information, developing their media competence.

\section{Conclusions}

There are several conclusions that can be drawn from this report. With respect to teaching, the course confirmed the effectiveness of the internet materials, especially the interviews with foreigners which were available on YouTube, as a factor motivating learners to "meet" members of different cultures. Additionally, the presence of guest-students in the group proved very beneficial; the Erasmus students created a real life environment in which students could practice their intercultural communication skills. In fact, the intercultural composition of the group was evaluated in a very positive way by the students themselves (question 9 in the questionnaire received a high mean score of 4.59). An activity that was extremely effective was asking students to prepare presentations based on their own topic. It allowed personalization - an approach that seems important particularly in intercultural training.

It is important to stress the role of the questionnaire in this study. It was a useful tool and provided valuable feedback from the students, which will be useful in preparing new courses in the future. The results obtained from the questionnaire and the observations of the classes underline a necessity to view this area of teaching within a more integrated perspective (cf. Wilczyńska 2013). Developing ICC as a goal in FL education involves focusing on a number of skills - those related to intercultural competence and those concerning FL competence, critical thinking and media competence, to mention just a few. All of these should be addressed by educators at the 
course designing stage. It is also crucial to realize that developing ICC is a personal experience that sometimes can be surprising or unpleasant for learners; as Byram (1997) assumes, it may involve experiencing rapid changes in one's attitudes.

The main goal of the course described in the present paper was to design classes which would enhance students' intercultural competence. Although the instruments applied did not allow the measurement of the learners' competence in a numerical way, the conclusions drawn from the questionnaire and observation of the classes imply that the students changed their ideas of what intercultural communication is. The comments they produced during the classes and in the questionnaire suggest that their ideas are more complex than the ones which they expressed at the beginning of the course, which may indicate a positive change in the development of their ICC.

It is hoped that this paper will contribute to discussions that focus on developing ICC. More research is needed to investigate the role of personalization and individualization in ICC courses. More focus should be placed on techniques required to evaluate students' existing ICC and its development.

\section{References}

Aleksandrowicz-Pędich, Lucyna (2009). "Intracultural dialogue during intercultural activities". In: Monika Kusiak (ed.). Dialogue in Foreign Language Education. Kraków: Wydawnictwo Uniwersytetu Jagiellońskiego, 23-33.

Aleksandrowicz-Pedich, Lucyna (2011). Review of the book. In: Anna Niżegorodcew, Yakiv Bystrov, Marcin Kleban (eds.). Developing Intercultural Competence Through English: Focus on Ukrainian and Polish Cultures. Kraków: Wydawnictwo Uniwersytetu Jagiellońskiego, fourth cover.

Byram, Michael (1997). Teaching and Assessing Intercultural Communicative Competence. Clevedon: Multilingual Matters.

Council of Europe. The Common European Framework of Reference for Languages: Learning, Teaching, Assessment. Available at 
<http://www.coe.int/en/web/common-european-framework-refere nce-languages $>$. Accessed 5.07.2017.

Dryjańska, Agnieszka (2016). "Słowa-wartości: interkulturowość ukryta w językach”. Neofilolog 47/1: 37-52.

Jankowska, Iwona, Marta Bodzioch (2016). "Trening akulturacyjny a rozwijanie interkulturowej kompetencji komunikacyjnej”. Neofilo$\log$ 46/2: 221-234.

Kapuściński, Ryszard (2006). Ten Inny. Kraków: Wydawnictwo Znak.

Krajowe Ramy Kwalifikacyjne (KRK). Rozporzadzenie Ministra Nauki i Szkolnictwa Wyższego 2/11/ 2011 r. w sprawie Krajowych Ram Kwalifikacji dla Szkolnictwa Wyższego.

Kramsch, Claire (2010). "Language and culture". In: James Simpson (ed.). Routledge Handbook of Applied Linguistics. New York: Routledge, 305-317.

Niżegorodcew, Anna, Yakiv Bystrov, Marcin Kleban (eds.) (2011). Developing Intercultural Competence Through English: Focus on Ukrainian and Polish Cultures. Kraków: Wydawnictwo Uniwersytetu Jagiellońskiego.

Piller, Ingrid (2007). "Linguistics and Intercultural Communication". Language and Linguistic Compass 1/3: 208-226.

Piotrowska-Paprocka, Urszula (2007). "Stereotyp w dialogu interkulturowym - wprowadzenie do warsztatu”. In: Maria Jodłowiec, Anna Niżegorodcew (eds.). Dydaktyka języków obcych na początku XXI wieku. Kraków: Wydawnictwo Uniwersytetu Jagiellońskiego, 287292.

Recommendation of the European Parliament and the Council on Key Competences of 18 December 2006 for Lifelong Learning. Available at <http://enil.ceris.cnr.it/Basili/EnIL/gateway/europe/EUkeyco mpetences.htm>. Accessed 20.07.2017.

Scollon, Ron, Suzanne Wong Scollon (2000). Intercultural Communication: A Discourse Approach. Oxford, UK: Blackwell.

Siek-Piskozub, Teresa (2016). "Kompetencja międzykulturowa - koncepcje i wyzwania". Neofilolog 46/2: 137-152.

Strugielska, Ariadna (2016). "Językoznawstwo kognitywne a rozumienie kompetencji międzykulturowej w kontekście umiędzynarodowienia szkolnictwa wyższego w Polsce”. Neofilolog 47/1: 93-107.

Wierzbicka, Anna (2013). Słowa klucze: Różne języki - różne kultury. Warszawa: Wydawnictwo Uniwersytetu Warszawskiego.

Wilczyńska, Weronika (2013). "Integrating intercultural (IC) and media competence: The DSK affair from a cross-cultural perspective". 
In: Elżbieta Mańczak-Wohlfeld, Maria Jodłowiec (eds.). Exploring the Microcosm and Macrocosm of Language Teaching and Learning. Kraków: Wydawnictwo Uniwersytetu Jagiellońskiego, 181-196.

\section{Online teaching materials}

18 surprising things you didn't know about Poland. Available at $<$ https://www.youtube.com/watch?v=0URwA8DT2ok>. Accessed 26.07.2016.

"Educating Rita". Educating Purposes Only. Available at <https:// www.youtube.com/watch?v=py8AgB5kyc4>. Accessed 2.10.2015.

"POLANDIA - Paola (Norwegia/Norway)". Available at <https:// www.youtube.com/watch?v=B40WJY-5L1g> . Accessed 4.11.2016.

"What about Poland. Geert Hofstede." Available at <https://geerthofstede.com/poland.html>. Accessed 06.11.2016.

\section{Appendix}

The questionnaire for the students to evaluate the course

The aim of this questionnaire is to know your opinions about the Intercultural Communication classes you had last semester. Please, read the statements below and in each case mark the answer that best suits your opinion. The questionnaire is anonymous.

Nationality:

Age:

Sex:

I. For the following statements circle the number that reflects how much you agree with them.

1 - I totally disagree; 2 - I disagree to some extent; 3 - I don't know; 4 - I agree to some extent; 5 - I completely agree

1. The classes helped me to learn more about different cultures (e.g. countries, groups of people) and their customs, traditions, ways of thinking.

2. The classes helped me to become more aware of possible conflicts between different cultures.

12345

12345

3. The classes helped me to understand better why different cultures may experience difficulty in communicating. 
4. The classes helped me to understand better members of other cultures (other countries, communities).

5. The classes helped me to reflect on myself as a member of some cultures (e.g. your country, some communities) and my skills to communicate with other cultures.

6. The classes helped me to develop tolerance towards members of other cultures (i.e. those to which I don't belong).

7. The classes encouraged me to reflect on (think more about) the culture of my own country.

8. The classes helped me to improve the skills of discussing various aspects of intercultural communication.

9. The fact the group consisted of students coming from different countries (Poland, Ukraine) made the classes more interesting.

The classes helped me to practice:

\begin{tabular}{|l|l|}
\hline 10. reading skills (also reading the Internet materials) & 12345 \\
\hline 11. writing skills & 12345 \\
\hline 12. speaking skills & 12345 \\
\hline 13. presentation skills & 12345 \\
\hline 14. cooperating with other students & 12345 \\
\hline
\end{tabular}

\section{Evaluate the following topics discussed during the classes. For each example, circle one number:}

1 - I didn't like it at all; 2 - I didn't like it; 3 - It's difficult to say; 4 - I liked it to some extent; 5 - I definitely liked it

\begin{tabular}{|l|l|}
\hline $\begin{array}{l}\text { 15. The interview with the Norwegian girl studying } \\
\text { in Poland }\end{array}$ & 12345 \\
\hline 16. Intercultural conflicts in 'Educating Rita" & 12345 \\
\hline 17. Stereotypes about Ukrainian men and women & 12345 \\
\hline 18. Do Polish students cheat at exams? & 12345 \\
\hline 19. The nature of an intercultural shock & 12345 \\
\hline 20. Differences between different countries & 12345 \\
\hline $\begin{array}{l}\text { 21. } 18 \text { surprising things you didn't know about Poland } \\
\text { (a fact or a stereotype) }\end{array}$ & 12345 \\
\hline
\end{tabular}

\section{Evaluate the following activities we did during the classes. For each example, circle one number.}

\begin{tabular}{|l|l|}
\hline 22. The teacher's presentation & 12345 \\
\hline 23. Watching a film & 12345 \\
\hline 24. Writing an essay & 12345 \\
\hline
\end{tabular}




\begin{tabular}{|l|l|}
\hline 25. Watching YouTube videos & 12345 \\
\hline 26. Reading articles & 12345 \\
\hline 27. Preparing and conducting the presentation & 12345 \\
\hline 28. Watching other students' presentations & 12345 \\
\hline 29. Discussions about the material read or watched & 12345 \\
\hline
\end{tabular}

\section{Answer the following questions in English or Polish.}

What did you like about the fact that you had to prepare a presentation? What didn't you like about this task?

If you were to take the course again, what other topics connected with Intercultural Communication would you like to discuss?

What activities would you like to do?

Other comments about the classes:

Monika Kusiak-Pisowacka

ORCID iD: 0000-0002-4043-9144

Uniwersytet Jagielloński

Instytut Filologii Angielskiej

al. Mickiewicza 9A

31-120 Kraków

Poland

monika.kusiak@interia.pl 